\title{
Evaluation of diastolic functions by transthoracic echocardiography after stenting in patients with carotid artery stenosis
}

Ocena czynności rozkurczowej w echokardiografii przezklatkowej po zabiegu stentowania u chorych ze zwężeniem tętnicy szyjnej

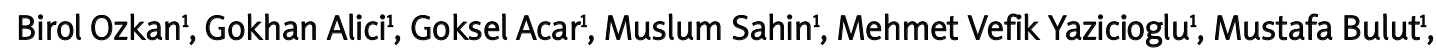 \\ Osman Gazi Kiraz², Ali Metin Esen ${ }^{1}$
}

1Department of Cardiology, Kartal Kosuyolu Yuksek Ihtisas Education and Research Hospital, Turkey

2Department of Anesthology, Kartal Kosuyolu Yuksek Ihtisas Education and Research Hospital, Turkey

Postep Kardiol Inter 2012; 8, 4 (30): 325-328

DOI: $10.5114 /$ pwki.2012.31913

\begin{abstract}
Background: Although carotid stenting is an effective treatment for severe carotid stenosis, it has been associated with alterations in autonomic functions (which may influence diastolic parameters) during or shortly after the procedure.

Aim: To determine whether there is any relation between the alteration in autonomic functions and diastolic functions by transthoracic echocardiography (TTE).

Material and methods: Patients (15 male, 7 female) who were suitable for carotid artery stenting, without a history of hypertension, diabetes mellitus, or severe coronary artery or valvular heart disease, were enrolled in our study. Transthoracic echocardiography recordings were obtained before, and the day after the procedure. E wave velocity, A wave velocity, E/A ratio, mitral E wave deceleration time (DT), isovolumic relaxation time (IVRT), and by using tissue Doppler echocardiography $\mathrm{Ea}, \mathrm{Aa}, \mathrm{Ea} / \mathrm{Aa}$ and $\mathrm{E} / \mathrm{Ea}$ ratios were measured. Results were statistically analysed using Friedman and Wilcoxon tests.

Results: While $E$ wave velocity, and E/A ratio increased non-significantly $(78 \pm 20,0.88 \pm 0.17 / 82 \pm 20,0.96 \pm 0.22)$, A wave and Aa velocities did not change after the procedure $(87 \pm 18,8.5 \pm 1.6 / 88 \pm 21,8.6 \pm 1.5)$. The value of Ea increased significantly $(9 \pm 1.7 / 9.9 \pm 2)$ and the E/Ea ratio decreased non-significantly after the procedure $(8.6 \pm 1.1 / 7.8 \pm 1.9)$. Values of IVRT and DT decreased significantly after the procedure $(91 \pm 16,220 \pm 44 / 86 \pm 18,200 \pm 23)$.

Conclusions: Sympathetic overactivity may impair diastolic functions. By carotid artery stenting, which is associated with an increase in parasympathetic activity by a vagally mediated stimulus, diastolic functions may improve. In our study, echocardiographic parameters showed improvement in diastolic functions.
\end{abstract}

Key words: carotid stenting, diastolic functions, echocardiography

\section{Streszczenie}

Wstęp: Stentowanie jest skuteczną metodą leczenia ciasnego zwężenia tętnicy szyjnej, ale wiąże się z zaburzeniami ze strony układu autonomicznego w trakcie lub krótko po zabiegu. Czynność układu autonomicznego może wpływać na parametry czynności rozkurczowej.

Cel: Wykazanie zależności między zaburzeniami czynności układu autonomicznego a czynnością rozkurczową w echokardiografii przezklatkowej (transthoracic echocardiography - TTE).

Materiał i metody: Do badania włączono 22 pacjentów (15 mężczyzn, 7 kobiet) kwalifikowanych do zabiegu stentowania tętnicy szyjnej, bez wywiadu nadciśnienia, cukrzycy, zaawansowanej choroby wieńcowej lub zastawkowej choroby serca. Oceny za pomocą TTE dokonywano przed zabiegiem oraz dzień po nim. Analizowano prędkość fal E i A, wskaźnik E/A, czas deceleracji (DT) fali E, czas relaksacji izowolumetrycznej (isovolumic relaxation time - IVRT), a także Ea, Aa oraz wskaźniki Ea/Aa i E/Ea za pomocą dopplera tkankowego. Wyniki analizowano statystycznie z wykorzystaniem testów Friedmana i Wilcoxona.

Corresponding author/Adres do korespondencji:

Gokhan Alici MD, Kartal Kosuyolu Yuksek Ihtisas Education and Research Hospital, Denizer Caddesi, Cevizli, 34000 Istanbul, Turkey,

tel.: +905326852119, e-mail: gokhanalici@yahoo.com

Praca wpłynęła: 12.05.2012, przyjęta do druku: 30.10.2012. 
Wyniki: Stwierdzono nieistotny wzrost prędkości fali E i wskaźnika E/A (78 $\pm 20,0,88 \pm 0,17 / 82 \pm 20,0,96 \pm 0,22)$ oraz brak zmian prędkości fali A i Aa po zabiegu $(87 \pm 18,8,5 \pm 1,6 / 88 \pm 21,8,6 \pm 1,5)$. Obserwowano istotne zwiększenie wartości Ea $(9 \pm 1,7 / 9,9 \pm 2)$ i nieistotne zmniejszenie wartości wskaźnika E/Ea $(8,6 \pm 1,1,7,8 \pm 1,9)$ po zabiegu. Wartości IVRT i DT zmniejszyły się znacząco po zabiegu $(91 \pm 16,220 \pm 44 / 86 \pm 18,200 \pm 23)$.

Wnioski: Nadreaktywność układu współczulnego może upośledzać czynność rozkurczową. Stentowanie tętnicy szyjnej wiąże się ze wzrostem aktywności przywspółczulnej poprzez bodźce z nerwu błędnego, co może wpływać na poprawę czynności rozkurczowej. W przedstawionym badaniu za pomocą parametrów echokardiograficznych wykazano poprawę czynności rozkurczowej.

Słowa kluczowe: stentowanie tętnicy szyjnej, czynność rozkurczowa, echokardiografia

\section{Introduction}

Carotid artery stenting (CAS) has emerged as an alternative procedure to carotid artery endarterectomy for the treatment of carotid atherosclerotic disease [1]. Hemodynamic fluctuation occurs during CAS due to stretching of the carotid sinus baroreceptors, mainly during balloon dilatation. The impact of this phenomenon on prognosis and outcomes is still controversial [2, 3].

The changes in carotid baroreceptor activity, which operates through the autonomic nervous system, may influence diastolic filling patterns [4-6].

\section{Aim}

The purpose of this study was to investigate any changes in diastolic functions evaluated by transthoracic echocardiography (TTE) in the first 24-hour period after the CAS procedure.

\section{Material and methods}

In the period of November 2010 to December 2011, twenty-seven consecutive patients with extracranial internal carotid artery stenosis due to atherosclerosis who were eligible for CAS were included in our study. Internal carotid artery stenosis was associated with diameter reduction, more than $70 \%$ in symptomatic patients and $80 \%$ in asymptomatic patients, measured per NASCET (North American Symptomatic Carotid Endarterectomy Trial Collaborators) criteria [7]. Patients with cardiac arrhythmias, pacemakers, a history of coronary artery disease, hypertension, diabetes mellitus, or valvular heart disease and treated with medications that may interfere with autonomic activity such as $\beta$-blockers were excluded. Written informed consent was obtained from all patients.

All patients received $300 \mathrm{mg}$ of acetyl salicylic acid and $75 \mathrm{mg}$ of clopidogrel daily for at least 3 days prior to the procedure. Carotid artery stenting was performed through a femoral approach, using a self-expanding Carotid Wallstent (Boston Scientific) or Protege Rx carotid stent system (EV3), equipped with a embolic protection device, and Filter EZ (Boston Scientific). Balloon post-dilatation was routinely performed once with a 4.5-5.0 mm diameter balloon. All patients received an intravenous dose of $1 \mathrm{mg}$ atropine at the time of balloon dilatation. After CAS, vital and neurological signs of patients were monitored for a minimum of $24 \mathrm{~h}$.

All participants underwent a complete TTE (2-dimensional, pulsed-wave Doppler transmitral recordings, and tissue Doppler imaging (TDI) recordings of mitral annular velocity examination) prior to the procedure ( $1^{\text {st }}$ measurement) and the following day ( $2^{\text {nd }}$ measurement) by using a commercially available machine (Vivid 7, GE-Vingmed, Horten, Norway) with a 3.5-MHz transducer (GE-Vingmed, Horten, Norway). Two-dimensional and pulsed-wave Doppler echocardiographic studies were performed in the left lateral decubitus position with conventional views (parasternal long- and short-axis, apical 4-chamber). An electrocardiogram was recorded simultaneously with its tracings on the Doppler monitor. Mitral inflow velocity was recorded from the apical 4-chamber view by pulsed-wave Doppler sampling during diastole. Peak early (E) and late (A) mitral inflow velocity, E/A ratio, and deceleration time (DT) of E velocity were obtained. Isovolumetric relaxation time of the left ventricle (IVRT) was obtained as the time interval from the cessation of LV outflow to the onset of mitral valve inflow. Tissue Doppler imaging of the mitral annulus velocities was applied at the lateral sides with the same echocardiographic unit in the pulsed-Doppler mode. Systolic, early diastolic (Ea) and late diastolic (Aa) velocities were measured, and $\mathrm{Ea} / \mathrm{Aa}$ and $\mathrm{E} / \mathrm{Ea}$ ratios were calculated. Echocardiographic examination was performed by an experienced investigator who was unaware of the clinical details.

\section{Statistical analysis}

Statistical analysis was performed using the Statistical Package for Social Sciences' (SPSS, Chicago, IL), version 15.0 software for Windows. Wilcoxon test was used for the comparison of variables. Data are presented as mean \pm standard deviation. Values of $p<0.05$ were regarded as significant.

\section{Results}

Table 1 lists the characteristics of the 27 patients with extracranial internal carotid artery stenosis included in our study. All CAS interventions were done successfully without any adverse neurological events. The male/female ratio was $19 / 8$. The mean age was $66 \pm 11$ years (range: $36-80$ 
Table 1. Baseline characteristics of study population Tabela 1. Podstawowa charakterystyka badanej grupy

\begin{tabular}{lc} 
Age [years] & $66 \pm 11$ \\
\hline Men/women & $19 / 8$ \\
\hline Stenosis degree [\%] & $84 \pm 12$ \\
\hline Stenosis side (left/right) & $19 / 8$
\end{tabular}

years). All patients had unilateral stenosis, where the mean degree of stenosis was $84 \pm 12 \%$.

While $E$ wave velocity and $E / A$ ratio increased non-significantly ( $1^{\text {st }}$ measurement: $78 \pm 20,0.88 \pm 0.17 ; 2^{\text {nd }}$ measurement: $82 \pm 20,0.96 \pm 0.22$; $p$ value: non-significant - NS), $A$ wave and $A a$ velocities did not change after the procedure $\left(1^{\text {st }}\right.$ measurement $87 \pm 18,8.5 \pm 1.6 ; 2^{\text {nd }}$ measurement: $88 \pm 21,8.6 \pm 1.5$; $p$ value: NS). Ea value increased significantly ( $1^{\text {st }}$ measurement: $9 \pm 1.7 ; 2^{\text {nd }}$ measurement: $9.9 \pm 2$; $p$ value $<0.05)$ and $\mathrm{E} / \mathrm{Ea}$ ratio decreased non-significantly after the procedure $\left(1^{\text {st }}\right.$ measurement: $8.6 \pm 1.1 ; 2^{\text {nd }}$ measurement: $7.8 \pm 1.9$; $p$ value: NS). The value of IVRT and DT decreased significantly after the procedure (1 $1^{\text {st }}$ measurement: $91 \pm 16,220 \pm 44 ; 2^{\text {nd }}$ measurement: $86 \pm 18,200 \pm 23$; $p$ value< 0.05 ) (Table 2 ).

\section{Discussion}

The present study mainly showed that while IVRT and DT decreased, and Ea wave velocity increased significantly, mitral $\mathrm{E}$ wave velocity and $\mathrm{E} / \mathrm{A}$ ratio increased, and $\mathrm{E} / \mathrm{Ea}$ decreased non-significantly on the following day after the CAS procedure. These findings suggest an improvement in diastolic functions, which may be a reflection of parasympathetic dominance that occurs after CAS.

The carotid sinus baroreceptors are the most important regulatory mechanism in control of blood pressure and heart rate. Changes in baroreceptor activity may cause hemodynamic fluctuations, as observed after CAS [8]. The baroreceptors are stretch receptors that are stimulated by distention of the arterial wall due to changes in blood pressure. The carotid sinus baroreceptors, which are innervated by the carotid sinus nerve, provide continuous information to the central nervous system about changes in blood pressure. Activation of the central nervous system leads to an increase of the discharge of vagal cardioinhibitory neurons and a decrease in the discharge of sympathetic neurons both to the heart and peripheral blood vessels. This results in bradycardia, decreased cardiac contractility and decreased peripheral vascular resistance, and venous return [9].

Carotid artery endarterectomy and CAS may have differential effects on sympathovagal balance of the heart. While a deviation in cardiac autonomic balance towards the sympathetic side occurs after carotid artery endarterectomy, parasympathetic dominance is seen after CAS.
Table 2. Comparison of echocardiographic parameters prior to and the day after the CAS procedure Tabela 2. Porównanie parametrów echokardiograficznych przed zabiegiem oraz dzień po zabiegu stentowania tętnicy szyjnej

\begin{tabular}{lccc} 
Parameters & $\begin{array}{c}1^{\text {st }} \\
\text { measurement }\end{array}$ & $\begin{array}{c}2^{\text {nd }} \\
\text { measurement }\end{array}$ & Value of $p$ \\
\hline E wave velocity $[\mathrm{cm} / \mathrm{s}]$ & $78 \pm 20$ & $82 \pm 20$ & NS \\
\hline A wave velocity $[\mathrm{cm} / \mathrm{s}]$ & $87 \pm 18$ & $88 \pm 21$ & NS \\
\hline E/A ratio & $0.88 \pm 0.17$ & $0.96 \pm 0.22$ & NS \\
\hline Ea wave velocity $[\mathrm{cm} / \mathrm{s}]$ & $9 \pm 1.7$ & $9.9 \pm 2$ & $<0.05$ \\
\hline Aa wave velocity $[\mathrm{cm} / \mathrm{s}]$ & $8.5 \pm 1.6$ & $8.6 \pm 1.5$ & $\mathrm{NS}$ \\
\hline E/Ea ratio & $8.6 \pm 1.1$ & $7.8 \pm 1.9$ & $\mathrm{NS}$ \\
\hline IVRT $[\mathrm{ms}]$ & $91 \pm 16$ & $86 \pm 18$ & $<0.05$ \\
\hline DT [ms] & $220 \pm 44$ & $200 \pm 23$ & $<0.05$
\end{tabular}

The alterations in cardiac autonomic functions after CAS may be related to the changes in baroreceptor functions. While compressing the atheromatous plaque into the arterial wall increases tension over the baroreceptors, CAS placement causes a continuous mechanical distension over the carotid bulbus. Both situations lead to inhibition of the sympathetic fibres and stimulation of the parasympathetic pathway. The incision of the carotid artery bulb during carotid artery endarterectomy can denervate baroreceptors, leading to elevation of sympathetic tone [10].

The relation between diastolic filling patterns and changes in autonomic functions described in this study may be due to the hemodynamic consequence of increased parasympathetic activity. Parasympathetic overactivity after the CAS procedure may improve ventricular relaxation, whereas sympathetic activity acts reversely [11]. In our study, while Ea wave velocity increased significantly, E wave velocity increased non-significantly. Firstly, this may be related to a close relationship between tissue Doppler data and autonomic tonus [12]. Secondly, transmitral flow is highly dependent on other factors affecting volume and transmitral flow [13].

To the best of our knowledge, this is the first investigation to examine diastolic functions by TTE after CAS. The results showed improvement in diastolic functions after CAS in the first 24-hour period. Whether this improvement after CAS is transient or permanent is beyond our study aim. However, Mangin et al. reported an immediate influence on cardiac autonomic control after CAS [8]. Also, Yakhou et al. observed parasympathetic dominance in comparison of short-term (8- and 24-hour post-procedure) effects on cardiac baroreflex, as well as autonomic cardiovascular control in CAS patients, but not in carotid artery endarterectomy patients [14]. On the other hand, Huang et al. suggested reduced baroreceptor function as transient rather than permanent [15].

The first limitation of our study is the small sample size due to the need to exclude patients with hypertension, 
diabetes mellitus, severe coronary artery disease or valvular heart disease, and patients on medications interfering with autonomic functions. The second limitation is that due to not having a control group, a comparison of diastolic function parameters could not be done.

In conclusion, improvement in diastolic functions after CAS may be associated with parasympathetic overactivity. Further studies in larger populations are needed to confirm these findings.

\section{References}

1. Knur R. Carotid artery stenting: a systematic review of randomized clinical trials. Vasa 2009; 38: 281-291.

2. Dangas G, Laird JR Jr, Satler LF, et al. Postprocedural hypotension after carotid artery stent placement: predictors and short- and long-term clinical outcomes. Radiology 2000; 215: 677-683.

3. Gupta R, Abou-Chebl A, Bajzer CT, et al. Rate, predictors, and consequences of hemodynamic depression after carotid artery stenting. J Am Coll Cardiol 2006; 47: 1538-1543.

4. Arora R, Krummerman A, Vijayaraman $P$, et al. Heart rate variability and diastolic heart failure. Pacing Clin Electrophysiol 2004; 27: 299-303.

5. Ishise H, Asanoi H, Ishizaka S. Time course of sympathovagal imbalance and left ventricular dysfunction in conscious dogs with heart failure. J Appl Physiol 1998; 84: 1234-1241.

6. Stein PK, Tereshchenko L, Domitrovich PP, et al. Diastolic dysfunction and autonomic abnormalities in patients with systolic heart failure. Eur J Heart Fail 2007; 9: 364-369.

7. NASCET Collaborators. Beneficial effect of carotid endarterectomy in symptomatic patients with high-grade carotid stenosis. N Engl J Med 1991; 325: 445-453.

8. Mangin L, Medigue C, Merle JC, et al. Cardiac autonomic control during balloon carotid angioplasty and stenting. Can J Physiol Pharmacol 2003; 81: 944-951.

9. La Rovere MT, Pinna GD, Raczak G. Baroreflex sensitivity: measurement and clinical implications. Ann Noninvasive Electrocardiol 2008; 13: 191-207.

10. Demirci M, Saribaș O, Uluç K, et al. Carotid artery stenting and endarterectomy have different effects on heart rate variability. J Neurol Sci 2006; 241: 45-51.

11. Dogru M.T, Gunaydin S, Simsek V, et al. Correlation of chronotropic index and heart rate recovery to heart rate variability and diastolic function values in men. The Internet Journal of Cardiology 2007; 4 (2).

12. Skaluba SJ, Litwin SE. Doppler-derived left ventricular filling pressures and the regulation of heartrate recovery after exercise in subjects with suspected coronary artery disease. Am J Cardiol 2005; 95: 832-837.

13. Thamilarasan M, Klein A. Restrictive cardiomyopathy. In: The practice of clinical echocardiography. Otto CM (ed). WB. Saunders, Philadelphia 2002; 619-620.

14. Yakhou L, Constant I, Merle JC, et al. Noninvasive investigation of autonomic activity after carotid stenting or carotid endarterectomy. J Vasc Surg 2006; 44: 472-479.

15. Huang CC, Wu YS, Chen T, et al. Long-term effects of baroreflex function after stenting in patients with carotid artery stenosis. Auton Neurosci 2010; 158: 100-104. 